\title{
Occlusive retinal vasculitis in an immunocompetent woman: rare presentation of ocular melioidosis
}

Abdul Satar Huwaina ${ }^{1,2}$, Mohamad Kamil Muhammad-Ikmal ${ }^{1,3}$, Muda Rosiah², Liza-Sharmini Ahmad Tajudin ${ }^{1}$

${ }^{1}$ Department of Ophthalmology and Visual Science, School of Medical Sciences, Universiti Sains Malaysia Health Campus, Kota Bharu, Kelantan, Malaysia; ${ }^{2}$ Department of Ophthalmology, Hospital Sultanah Nur Zahirah, Jalan Sultan Mahmud, Terengganu, Malaysia; ${ }^{3}$ Department of Surgical Based Discipline, Faculty of Medicine and Health Sciences, Universiti Malaysia Sabah, Kota Kinabalu, Sabah, Malaysia

\section{Abstract}

Burkholderia pseudomallei is a known great mimicker responsible for melioidosis. Melioidosis presents with a wide spectrum of clinical presentations in various organs including the eye. Ocular involvement in melioidosis is unusual, with eyelid and orbital infection as the commonest presentation. We describe a 41-year-old, healthy woman who complained of reduced vision in her left eye. On examination, vision in the left eye was 6/9. There was evidence of occlusive retinal vasculitis on fundoscopy examination. Fundus fluorescein angiogram showed extensive capillary fallout. Diagnosis was established by a rise in the serum antibody titre for the bacterium and further supported by clinical improvement of vision after completion of treatment antibiotics: third-generation cephalosporin and combination of amoxicillin and clavulanic acid. Sectoral panretinal photocoagulation at the capillary fallout area successfully arrested the sequelae of retinal ischaemia. Occlusive retinal vasculitis is a rare presentation of melioidosis. Early prompt diagnosis of ocular melioidosis in an immunocompetent individual helps prevent visual-related morbidity. The ability of this bacteria to cause recurrent infection in an endemic area should not be underestimated.

Correspondence: Dr. Liza-Sharmini Ahmad Tajudin, MBBS (Malaya), MMed (Ophthal) (USM), PhD (UK), AM (Malaysia), Professor of Ophthalmology and Senior Consultant Ophthalmologist (Glaucoma), Department of Ophthalmology and Visual Science, School of Medical Sciences, Universiti Sains Malaysia Health Campus, 16150 Kota Bharu, Kelantan, Malaysia. E-mail: liza@usm.my 
Keywords: Burkholderia pseudomallei, immunocompetence, melioidosis, occlusive retinal vasculitis

\section{Abstrak}

Burkholderia pseudomallei adalah organisma yang dikenali sebagai peniru yang agung adalah penyebab penyakit meliodosis. Meliodosis mempunyai spektrum klinikal yang meluas melibatkan pelbagai organ termasuk mata. Walaubagaimanapun penglibatan mata dalam penyakit ini adalah agak jarang berlaku. Sekiranya berlaku, jangkitan sering terjadi pada kelopak mata dan orbit. Di sini, kami memerihalkan seorang wanita yang sihat berumur 41 tahun yang menghadapi masalah kurang penglihatan pada mata kirinya. Pemeriksaan mata mendapati penglihatan pada mata kirinya adalah 6/9. Funduskopi mendapati terdapat bukti radang dan penyumbatan pada salurdarah retina. Ujian angiogram floresein fundus (fundus fluorescein angiogram [FFA]) menunjukkan keguguran atau penyumbatan kapilari secara meluas. Diagnosa dibuat berdasarkan kenaikkan titer antibodi dalam serum dan juga keberkesanan ke atas penglihatan mata setelah rawatan antibiotic diberikan iaitu generasi ketiga cefalosporin dan gabungan amoxicillin dan asid klavulanik. Kesan iskemia retinal dapat di hentikan dengan rawatan fotokoagulasi secara sektoral pada kawasan kapilari yang tersumbat. Radang dan penyumbatan salur darah retina adalah manifestasi klinikal yang amat jarang berlaku bagi meliodosis.

Kata kekunci: Burkholderia pseudomallei, kompeten imuniti, meliodosis, radang dan penyumbatan salurdarah

\section{Introduction}

Melioidosis is an infectious disease caused by a gram-negative, motile, non-spore forming facultative anaerobic bacillus known as Burkholderia pseudomallei. ${ }^{1}$ Melioidosis presents with a broad spectrum of clinical presentations and organ involvement. ${ }^{2}$ It can vary from a latent infection with an incubation period of up to 29 years to fulminant sepsis with a high mortality rate. ${ }^{3}$ Ocular involvement in melioidosis is rare and has devastating outcomes. ${ }^{2}$

Here we report a case presenting with occlusive retinal vasculitis secondary to melioidosis. We discuss possible appropriate early treatment and visual outcome in this rare ocular disease in an immunocompetent adult. 
Fig. 1. Fundus photograph showing swollen (irregular margin) and hyperemic optic disc of the left eye.

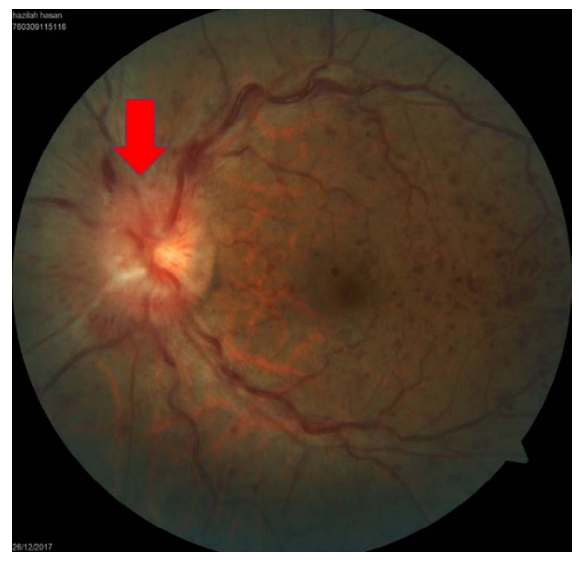

\section{Case presentation}

A 41-year-old, healthy woman presented with reduced vision in the left eye for 2 weeks. There was no ocular pain, redness, or discharge. She provided a history of contact with a pulmonary tuberculosis patient several years prior. There was no history of recent travel abroad, swimming in waterways, or any significant skin abrasion wound. She denied any productive cough, tachypnoea, or haemoptysis. She was afebrile and systemic review was unremarkable. She stated she enjoyed gardening in her free time.

On examination, vision in the left eye was $6 / 9$ and $6 / 6$ in the right eye. There was no relative afferent pupillary defect. Anterior segments of both eyes were unremarkable. Her left fundus showed a swollen, hyperaemic optic disc as well as multiple splinter haemorrhages with tortuous and dilated vessels (Fig. 1). There was also a vasculitic lesion seen on the optic disc. Multiple dot blot haemorrhages were seen in all four quadrants of the fundus. The macula appeared normal, without evidence of macula oedema. The vitreous was clear.

Thorough investigations were conducted, including connective tissue disease screening and computed tomography scan of the orbit, which were all negative. Mantoux test was negative and erythrocyte sedimentation rate was not elevated. Her chest X-ray and electrocardiography (ECG) appeared normal. There was positive IgM titre for B. pseudomallei (1:320). However, there was no clinical sign to suggest systemic melioidosis infection. Fundus fluorescein angiography (FFA) showed leakage from the disc vessels and small vessel vasculitis with extensive areas of capillary fallout (CFO), suggestive of occlusive vasculitis (Fig. 2). Sectoral pan retinal photocoagulation was done at the area of capillary nonperfusion (Fig. 3).

She was initially treated empirically as presumed ocular tuberculosis based on clinical presentation, but treatment was stopped due to deranged liver enzymes. 

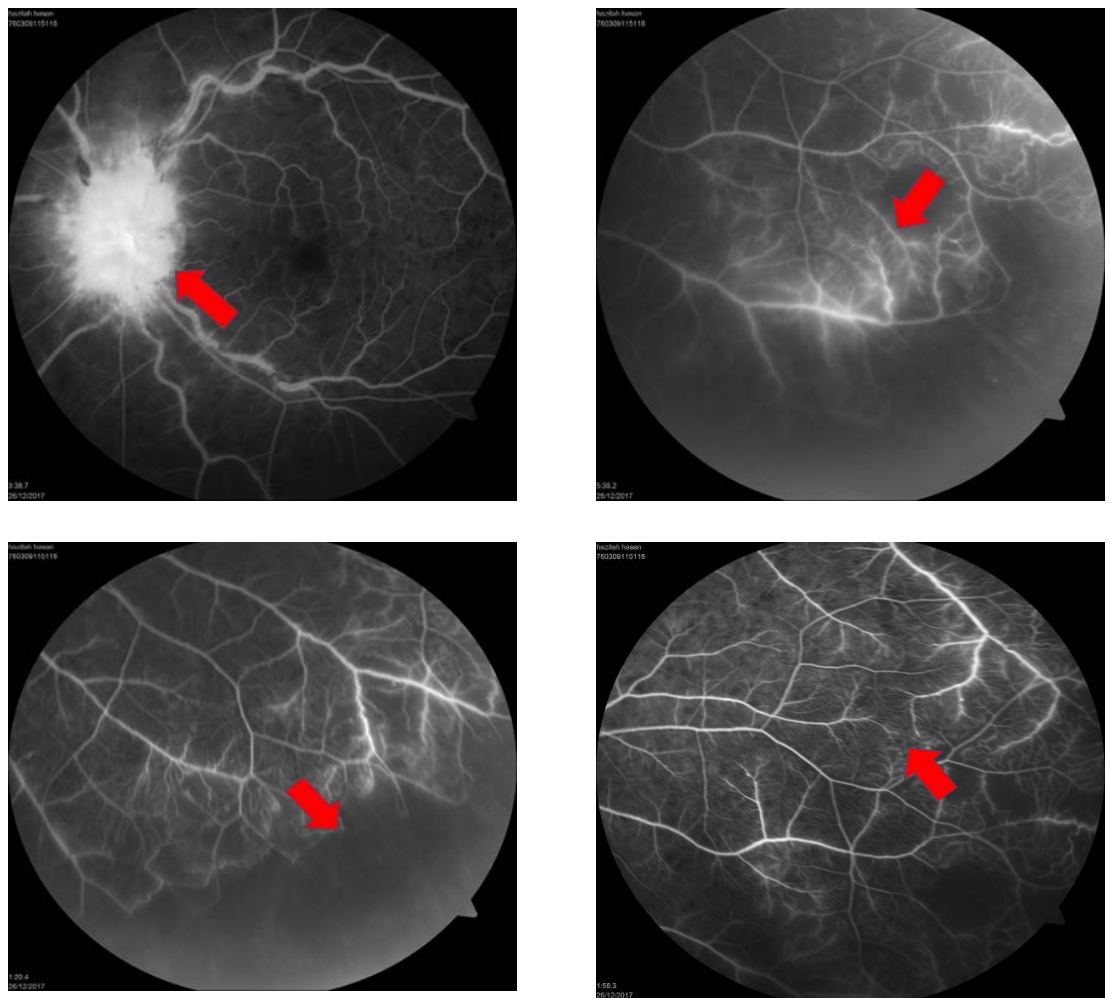

Fig. 2. FFA showing presence of leakage from the optic disc, extensive area of capillary fallout and small vessels vasculitis.

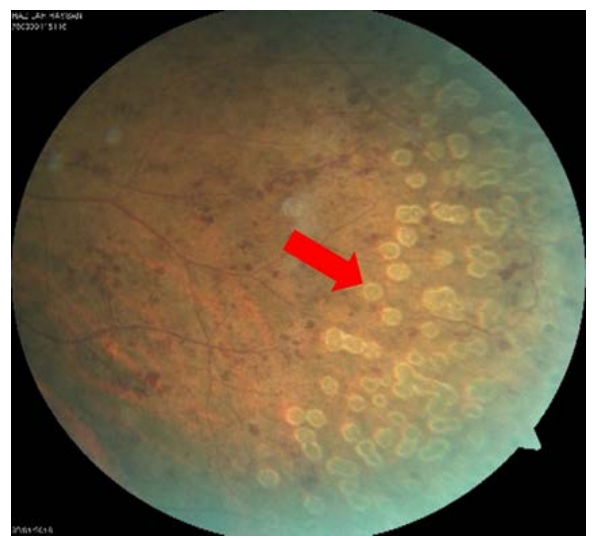

Fig. 3. Fundus photograph showing area of sectoral panretinal photocoagulation of the left eye.

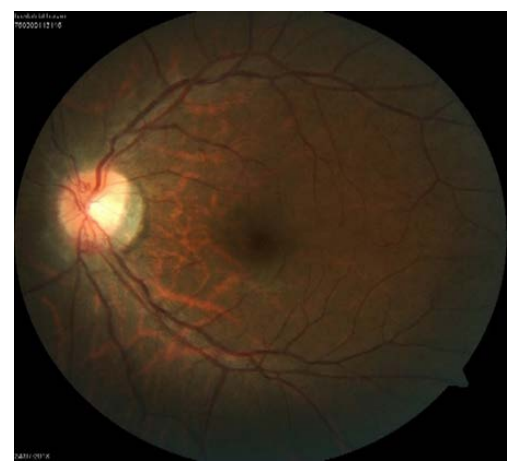

Fig. 4. Fundus photograph showing regular margin of disc (swelling resolved) and pink colored disc. There was no more haemorrhages seen and normal looking retinal vessels. 
Following the raised IgM titre for B. pseudomallei, she was then treated with intravenous ceftazidime for 2 weeks followed by oral amoxicillin-clavulanic acid. Her vision improved to $6 / 6$ and the optic disc swelling improved markedly (Fig. 4).

\section{Discussion}

Melioidosis is a multisystemic infectious disease caused by the gram-negative soil saprophyte $B$. pseudomallei, which is commonly found in contaminated water and soil. Melioidosis is endemic in Malaysia and other Southeast Asian countries and is responsible for high case-fatality rates. ${ }^{4}$ Infection is acquired by inhalation of dust, ingestion of contaminated water, and contact with contaminated soil, especially through skin abrasions. ${ }^{5,6}$ However, in endemic areas such as Malaysia, transmission can have several modes of entry. Thus, absence of skin abrasions may not exclude the possibility of melioidosis, as in this case. In fact, there was reported case of transmission through inhalation during the flight training in Singapore and monsoon season in Philippines. ${ }^{7,8}$ There were also reported cases of endophthalmitis following history of swimming in waterfalls in Malaysia. ${ }^{9}$

In the present case, there was no specific risk factor of exposure except for working with soil while gardening. The risk of melioidosis is reportedly higher in those with systemic diseases such as diabetes mellitus.,10 Although immunocompromised status increases the risk, there have been reported cases among healthy individuals as in this case. ${ }^{11}$ In Malaysia, $15-42 \%$ of melioidosis cases reported had no significant risk factors. ${ }^{10}$

In general, the clinical spectrum of melioidosis is wide, ranging from mild symptoms of flu-like illness to fatal septicaemia. ${ }^{8}$ Ocular manifestation is rare. The most common reported presentation is lid abscess and its sequelae: preseptal and orbital cellulitis. ${ }^{2,12,13}$ There was also a reported case of endophthalmitis in children with history of swimming in a waterfall. ${ }^{9}$ However, there have been no reported cases with direct retinal involvement.

Here, we reported a case of occlusive retinal vasculitis with positive serological detection of B. pseudomallei. We postulated that the septic bolus or embolus formed by this 'great mimicker' occluded the retinal vein and impeded blood flow. Symptoms were lacking to suggest recent infection and potential sites of entry were absent, pointing towards recurrence or relapse. The ability of $B$. pseudomallei to evade the immunological radar of human protective mechanisms and reach a dormant stage may explain the lack of symptoms. The question remains as to when the patient was initially infected. There are many suggested classifications or categories due to the nonspecific clinical presentation of melioidosis. ${ }^{8,10}$ Based on the review on melioidosis in Malaysia, ${ }^{10}$ her presentation was similar to the category of acute localized infection and remained localized without bacteraemic stage. She was perhaps partially treated with amoxicillin-clavulanate during the initial stage of 
localized infection, which may have presented as severe flu-like illness, long before this current infection. Perhaps, due to the unspecific presentation of melioidosis, this condition went unnoticed by this patient.

The next question is where these septic embolus and bolus originated. Septic emboli may originate from other parts of the body or direct formation in the retinal vein. There have been reported cases of mycotic abdominal pseudoaneurysm, pericardial effusion, and heart valve vegetation in Malaysia. ${ }^{11,14} \mathrm{Clinically,} \mathrm{there} \mathrm{was}$ no sign to suggest heart abnormalities based on the patient's ECG. ECG and Doppler sonography of the carotid artery was not conducted due to lack of indication in her case. Since the retinal vasculature is an end artery, a small primary or secondary embolus may impede the blood supply, causing occlusive retinitis. The presence of CFO on FFA indicated retinal vein obstruction and ischaemia. In the presence of retinal ischaemia, regardless of the cause, sectoral panretinal photocoagulation is indicated. ${ }^{15}$

The patient's history of contact with tuberculosis may have been a red herring and delayed the appropriate treatment. There have been reported cases of melioidosis mimicking tuberculosis. ${ }^{16}$ In addition, confirmation of $B$. pseudomallei is also challenging. The definitive diagnosis is based on culture of the organism from blood, sputum, urine, or pus. However, where the foci of infection are unknown or inaccessible to standard specimen collection techniques, (which occurs most commonly in subacute or chronic cases), nonbacteraemic melioidosis, diagnosis is made by serology. ${ }^{1}$ In Malaysia, current practice is using serological diagnosis with the optimized in-house ELISA as the method of choice for recent exposure to B. pseudomallei. Although the accuracy of this method remains to be proven, it is widely acceptable in Malaysia. ${ }^{17}$ Other modes of detection include indirect haemaglutination or complementary test, and recently, molecular diagnostic testing.

In this case, the IgM ELISA was elevated (1:320), which was considered as positive. No samples were taken from ocular fluids, including the vitreous. However, the elevated serum titre was considered adequate for initiation of treatment. In addition, the treatment showed clinical improvement in visual acuity and retinal findings. The patient's vision remained good until the time of writing.

\section{Conclusion}

Although not common, ocular melioidosis may be associated with devastating morbidity without proper management. Occlusive retinal vasculitis due to $B$. pseudomallei is rare. High index of suspicion in endemic areas, even in immunocompetent individuals, is important for initiation of early treatment and preservation of vision. 


\section{Declarations}

\section{Ethics approval and consent to participate}

Not required.

\section{Consent for publication}

The patient provided informed consent for the use of the clinical images and information contained in this case report.

\section{Competing interests}

None to declare.

\section{Acknowledgements}

None to declare.

\section{References}

1. White NJ. Melioidosis. The Lancet, 2003; 361(9370), 1715-1722. doi:10.1016/s0140-6736(03)13374-0

2. Yaisawang S, Asawaphureekorn S, Chetchotisakd P, Wongratanacheewin S, Pakdee P. Ocular involvement in melioidosis: a 23-year retrospective review. J Ophthalmic Inflamm Infect. 2018 Mar;8(1):1. https://doi.org/10.1186/s12348-018-0147-6

3. Cheng AC, Currie BJ. Erratum: Melioidosis: Epidemiology, pathophysiology, and management. Clin Microbiol Rev. 2007 Jul;18(2):383-416. https://doi.org/10.1128/CMR.00018-07

4. Chen KJ, Sun MH, Hou CH, Sun CC, Chen TL. Burkholderia pseudomallei endophthalmitis. J Clin Microbiol. 2007 Dec;45(12):4073-4. https://doi.org/10.1128/JCM.01467-07

5. Currie BJ, Fisher DA, Howard DM, Burrow JNC, Lo D, Selva-Nayagam S, et al. Endemic melioidosis in tropical northern Australia: A 10-year prospective study and review of the literature. Clin Infect Dis. 2000 Oct;31(4):981-6. https://doi.org/10.1086/318116

6. Carlson P, Seppänen M. Melioidosis presenting as urinary tract infection in a previously healthy tourist. Scand J Infect Dis. 2009 Jul;32(1):92-3. https://doi.org/10.1080/00365540050164308

7. Puthucheary SD. Melioidosis in Malaysia. Med J Malaysia. 2009 Dec;64(4):266-74. https://doi. org/10.4269/ajtmh.1969.18.703

8. Currie BJ. Melioidosis: Evolving concepts in epidemiology, pathogenesis, and treatment. Semin Respir Crit Care Med. 2015 Feb;36(1):111-25. https://doi.org/10.1055/s-0034-1398389

9. Feng WC, Teh W, Hitam W-H, Ali H. Endogenous endophthalmitis secondary to melioidosis in paediatric patients: Case series and review article. J Acute Dis. 2018 Dec;7(6):234. https://doi. org/10.4103/2221-6189.248027

10. Nathan S, Chieng S, Kingsley PV, Mohan A, Podin Y, Ooi MH, et al. Melioidosis in Malaysia: Incidence, clinical challenges, and advances in understanding pathogenesis. Trop Med Infect Dis. 2018 Feb;3(1):25. https://doi.org/10.3390/tropicalmed3010025 
11. Lu HT, Ramsamy G, Lee CY, Syed Hamid SRG, Kan FK, Nordin RB. A case of constrictive pericarditis associated with melioidosis in an immunocompetent patient treated by pericardiectomy. Am J Case Rep. 2018 Mac;19:314-9. https://doi.org/10.12659/AJCR.908310

12. Chang CY. Melioidosis presenting with periorbital cellulitis and eyelid abscess in Sarawak, Malaysian Borneo - A case report. Sri Lankan J Infect Dis. 2019 Oct;9(2):160. https://doi.org/10.4038/sljid. v9i2.8259

13. Chang CY. Periorbital cellulitis and eyelid abscess as ocular manifestations of melioidosis: A report of three cases in Sarawak, Malaysian Borneo. IDCases. 2020;19:e00683. https://doi.org/10.1016/j. idcr.2019.e00683

14. Rao J, Kaushal AS, Hoong CK. Abdominal aortic pseudoaneurysm secondary to melioidosis. Asian J Surg. 2009 Jan;32(1):64-9. https://doi.org/10.1016/S1015-9584(09)60012-9

15. Lee E, Sanjay S, Teoh S. The role of the TB T-spot test in patients with tubercular retinal vasculitis. Asian J Ophthalmol. 2016 Jan;14(3):137-43.

16. Vidyalakshmi K, Chakrapani M, Shrikala B, Damodar S, Lipika S, Vishal S. Tuberculosis mimicked by Melioidosis. Int J Tuberc Lung Dis. 2008 Nov;12(10):1209-15.

17. Vadivelu J, Puthucheary SD, Gendeh GS, Parasakthi N. Serodiagnosis of melioidosis in Malaysia. Singapore Med J. 1995 Jun;36(3):299-302. 